LBNL-49899

\title{
Energy Effects of Heat-Island Reduction Strategies in Toronto, Canada
}

\author{
Hashem Akbari* and Steven Konopacki \\ Heat Island Group \\ Lawrence Berkeley National Laboratory \\ Berkeley, California 94720 \\ Received 6 April 2002
}

\begin{abstract}
The effect of heat-island reduction (HIR) strategies on annual energy savings and peak-power avoidance of the building sector of the Greater Toronto Area is calculated, using an hourly building energy simulation model. Results show that ratepayers could realize potential annual energy savings of over $\$ 11 \mathrm{M}$ from the effects of HIR strategies. The residential sector accounts for over half $(59 \%)$ of the total savings, offices $13 \%$ and retail stores $28 \%$. Savings from cool roofs are about $20 \%$, shade trees $30 \%$, wind shielding of trees $37 \%$, and ambient cooling by trees and reflective surfaces $12 \%$. These results are preliminary and highly sensitive to the relative price of gas and electricity. Potential annual electricity savings are estimated at about $150 \mathrm{GWh}$ and potential peak-power avoidance at $250 \mathrm{MW}$.
\end{abstract}

\section{Introduction}

During the summer, solar-reflective roofs (also known as "high-albedo" 1 " or "cool" roofs) reflect most of the incoming sunlight and reduce the amount of heat conduction into a building. Similarly, strategically placed trees, shading windows and walls of a building, reduce the amount of direct heat gain. The reduction in summer heat gain because of cool roofs and deciduous shade trees reduces the airconditioning load of a building, improves thermal comfort, saves peak-demand electricity, and saves money. During the winter, cool roofs and the shading effects of trees may add to the heating load of a building. However, the heating-energy penalties are small, since typically most of the heating is required during the evening hours with little or no sunshine, winter days are shorter and cloudier than summer days, and buildings may have snow on the roofs. Furthermore, trees can actually save heating-energy bills by shielding a building from cold winter wind [1].

Cool surfaces (roofs and pavements) together with urban vegetation (shade trees, park trees, lawn, etc.) can potentially cool the city by several degrees. Lowered urban air temperatures can further reduce

\footnotetext{
* Corresponding Author. Tel: 510-486-4287; Fax: 510-486-4673, E_mail: H_Akbari@LBL.gov.

${ }^{1}$ Albedo (â) is the ratio of the reflected over the incoming solar radiation.
} 
cooling-energy demand. More importantly, cooler ambient conditions can slow the rate of smog $\left(\mathrm{O}_{3}\right)$ formation and have a significant effect on ambient air quality [2].

Summertime temperatures in Toronto have been steadily increasing with the expansion of the city [3]. In addition, most new buildings are equipped with air-conditioners. As a result, the local utility company has changed from a winter-peaking to a summer-peaking utility. The effect of higher temperatures in the summer can potentially make air-quality problems more severe.

Energy savings from the use of solar-reflective roofs and shade trees have been predicted through computer simulations and verified with measured data in both residential and commercial buildings. The majority of these studies have focused on reflective roofs. Konopacki et al. [4] used computer simulations to estimate the net direct energy savings (cooling-energy savings minus heat-energy penalties) from reflective roofs on residential and commercial buildings in eleven U.S. Metropolitan Statistical Areas (MSAs). Metropolitan-wide savings were as much as \$37M for Phoenix and \$35M in Los Angeles and as low as $\$ 3 \mathrm{M}$ in the heating-dominated climate of Philadelphia. The results showed that three major building types accounted for over $90 \%$ of the annual electricity and monetary savings: old residences (55\%), new residences (15\%), and old/new office buildings and retail stores together (25\%).

In a recent study using a methodology similar to the pilot project, Konopacki and Akbari $[5,6]$ have estimated the direct and indirect energy effects of all heat-island reduction (HIR) measures in five U.S. metropolitan areas: Baton Rouge, Chicago, Houston, Sacramento and Salt Lake City. The analysis indicated that for the five respective cities, potential net annual energy savings of $\$ 15 \mathrm{M}, \$ 30 \mathrm{M}, \$ 82 \mathrm{M}$, \$26M, and \$3.6M, peak-power avoidance of 130MW, 400MW, 730MW, 490MW and 85MW.

Akbari and Taha [1] have estimated the effect of reflective surfaces and trees in four Canadian cities (including Toronto). The simulations indicated that by increasing the vegetative cover by $30 \%$, the heating-energy use in Toronto can be reduced by $10 \%$ in urban houses and $20 \%$ in houses located in open suburban areas (mostly because of wind-shielding effect of trees). Results also showed that by increasing the albedo of houses by 0.2 (from moderate-dark to medium-light color), the cooling-energy use can be reduced by about $30 \%-40 \%$. Other studies using computer simulations to estimate the effect of reflective roofs and trees include Konopacki and Akbari [7], Akbari et al. [8], Parker et al. [9], and Taha et al. [10].

In addition to computer simulations, several field studies have documented measured air-conditioning (a/c) summertime energy savings resulting from the use of solar-reflective roofs. These studies were conducted in warm climates (mostly in Florida and California). Konopacki and Akbari [11] have estimated daily energy savings of $39 \mathrm{Wh} / \mathrm{m}^{2}(11 \%)$ and peak-power reduction of $3.8 \mathrm{~W} / \mathrm{m}^{2}(14 \%)$ in a large retail store in Austin, Texas from the application of a reflective membrane. Akbari and Rainer [12] 
measured daily a/c energy savings of $33 \mathrm{Wh} / \mathrm{m}^{2}(1 \%)$ in two Nevada telecommunication regeneration buildings. Konopacki et al. [13] monitored the effect of reflective roofs in three California commercial buildings, two medical offices and one retail store. Summertime daily a $/ \mathrm{c}$ savings of $68 \mathrm{Wh} / \mathrm{m}^{2}, 39 \mathrm{Wh} / \mathrm{m}^{2}$ and $4.3 \mathrm{Wh} / \mathrm{m}^{2}(18 \%, 13 \%$ and $2 \%)$ and reduced demand of $3.3 \mathrm{~W} / \mathrm{m}^{2}, 2.4 \mathrm{~W} / \mathrm{m}^{2}$ and $1.6 \mathrm{~W} / \mathrm{m}^{2}(12 \%, 8 \%$ and 9\%) were measured. Akbari et al. [14] have shown that an increase in roof reflectance in one monitored Sacramento house resulted in daily summertime cooling-energy savings of $14 \mathrm{Wh} / \mathrm{m}^{2}(63 \%)$ and peak-power reduction of $3.6 \mathrm{~W} / \mathrm{m}^{2}(25 \%)$, and in a Sacramento school bungalow, cooling-energy savings of $47 \mathrm{Wh} / \mathrm{m}^{2}(46 \%)$ and peak-power reduction of $6.8 \mathrm{~W} / \mathrm{m}^{2}(20 \%)$. In an office, a museum and a hospice with reflective roofs in Sacramento, Hildebrandt et al. [15] measured daily a/c savings of $10 \mathrm{Wh} / \mathrm{m}^{2}, 20 \mathrm{Wh} / \mathrm{m}^{2}$ and $11 \mathrm{Wh} / \mathrm{m}^{2}(17 \%, 26 \%$ and 39\%). Parker et al. [9] monitored the effects of reflective roofs in eleven Florida residences with daily savings ranging from $5-137 \mathrm{Wh} / \mathrm{m}^{2}(2-43 \%)$ and peak-demand reduction of $1.5-7.7 \mathrm{~W} / \mathrm{m}^{2}$ (12-28\%). Parker and Sheinkopf [16] measured daily energy savings of $17 \%$ from a reflective roof in a high-efficiency home in Florida. Parker et al. [17] have also monitored seven retail stores within a strip mall in Florida before and after applying a reflective roof coating and measured a $7.5 \mathrm{Wh} / \mathrm{m}^{2}(25 \%)$ drop in daily summertime cooling-energy use and a $0.65 \mathrm{~W} / \mathrm{m}^{2}$ (29\%) decrease in demand. Parker et al. [18] measured daily energy savings of $44 \mathrm{Wh} / \mathrm{m}^{2}$ (25\%) and peakpower reduction of $6.0 \mathrm{~W} / \mathrm{m}^{2}(30 \%)$ from a reflective roof on a school building in Florida. Akridge [19] reported daily savings of $75 \mathrm{Wh} / \mathrm{m}^{2}(28 \%)$ for an education building in Georgia, the unpainted galvanized roof of which was coated with white acrylic. An office building in southern Mississippi was shown to save $22 \%$ after the application of a reflective roof coating [20].

In two monitored houses in Sacramento, Akbari et al. [21] have demonstrated that seasonal coolingenergy savings of $30 \%$ and peak-power savings of $35 \%$ can be realized with the placement of shade trees near the buildings.

The objective of this study was to make a preliminary assessment of the effects of HIR measures on building cooling- and heating-energy use and ambient air quality in the Greater Toronto Area (GTA). This paper summarizes our efforts to calculate the annual energy savings and peak-power avoidance resulting from the implementation of HIR strategies in the GTA. We focused on the effect of various HIR strategies on three major building types that offer the most savings potential: residence, office, and retail store. The HIR strategies included: (1) use of solar-reflective roofing material on buildings [direct effect], (2) placement of deciduous shade trees near south and west walls of buildings [direct effect], (3) placement of coniferous wind-shielding vegetation near buildings [direct effect], (4) effect of ambient cooling by a large-scale program of urban reforestation with reflective building roofs and pavements [indirect effect], and (5) combination of strategies 1-4 [direct and indirect effects]. 


\section{Methodology}

HIR measures have a significant effect on the energy use of low-rise residential and commercial buildings; they do not significantly affect the energy use of large multistory commercial or apartment buildings typically located in the downtown area [4]. Hence, we focused our efforts mostly on singlefamily residential and low-rise commercial buildings (offices and retail stores).

We modeled a total of nine building prototypes including five residential [pre-1980 (old) single-family houses, 1980+ (new) single-family houses, R-2000 single-family houses, pre-1980 (old) row-houses, 1980+ (new) row-houses; all modeled with both gas- and electric-heating systems], two office buildings [pre-1980 (old) offices, 1980+ (new) offices; both modeled with gas- and electric-heating systems], and two retail buildings [pre-1989 (old) retail buildings, 1980+ (new) retail buildings; both modeled with gasand electric-heating systems].

A four-step methodology was used to access the potential effects of HIR measures on prototype buildings and metropolitan-wide energy use in the GTA.

i. We defined prototypical building characteristics in detail for pre-1980 and 1980+ construction (and R-2000 single-family residence).

ii. We simulated annual cooling- and heating-energy use and peak demand using the DOE-2.1E model and determined direct and indirect energy and demand savings for each HIR strategy.

iii. We estimated the total roof area of air-conditioned buildings in the GTA, using existing data sources.

iv. We calculated the metropolitan-wide effects of HIR strategies.

\section{Building and Measure Descriptions}

Prototypical building data were identified and used to define construction, internal load, and cooling and heating equipment characteristics for residential, office, and retail buildings. The buildings were characterized for old (pre-1980: built prior to 1980) and new (1980+: built in 1980 or later) construction vintages; an R-2000 residence was also modeled. The prototypes were developed with both gas and electricity heating fuels. Considered were the use of existing and reflective roofs, the placement of deciduous shade trees about the south and west sides of the building, and coniferous trees to shield the building from cold winter wind. These data then defined the characteristics of the prototype building used by the DOE-2.1E energy simulation computer program. Building data for residences were obtained primarily from NRCAN [22,23] and Akbari and Taha [1]. 


\section{Residence}

The residence was modeled in two configurations: [1] single-family detached and [2] single-family rowhouse. The single-family structure was also modeled for R-2000 design. According to NRCAN [22], about $60 \%$ of existing single-family detached (SFD) houses are two-story and $23 \%$ single story; the average floor area is about $280 \mathrm{~m}^{2}$. The newer (1980+) SFD houses are about $90 \%$ two-story and $7 \%$ three-story (less than $3 \%$ are 1 -story); the average floor area is about $350 \mathrm{~m}^{2}$. For all existing row-houses, about $64 \%$ are two-story and $27 \%$ three-story; the average floor area is $170 \mathrm{~m}^{2}$. The newer (1980+) rowhouses were about $62 \%$ two-story and $37 \%$ three-story with an average floor area of about $150 \mathrm{~m}^{2}$. Prototypes for all residential buildings were modeled as 2-story buildings. Other major characteristics of the residential prototypes are summarized in Table 1 [24].

The roof was constructed with asphalt shingles on a $20^{\circ}$ sloped plywood deck, over a naturally ventilated and unconditioned attic, above a studded ceiling frame with fiberglass insulation (varying by vintage), and with a sheet of drywall beneath. The fractional-leakage-area of the attic and living quarters was dependent on vintage. Variable air infiltration was modeled by the Sherman-Grimsrud algorithm [25].

The prototype SFD residence was cooled and heated by a central air-conditioning system (with ducts located in the conditioned space), a constant volume fan, and without an economizer. The multi-family row-house was served by a ductless window or room a/c unit with heating provided by a gas wall furnace or electric resistance. Cooling through natural ventilation was available by window operation. System size and efficiency were selected for each vintage.

Modified part-load-ratio curves for a typical air-conditioner, heat pump and gas furnace were used in place of the standard DOE-2 curves, since they have been shown to model low-energy use more accurately [26]. Duct loads were simulated with a validated residential duct function [9] implemented into DOE-2 to better estimate the thermal interactions between the ducts and building thermal zones.

\section{Office}

The office was modeled as a single-story non-directional building with four perimeter zones and a core zone, also in two construction vintages: pre-1980 and 1980+. The floor plan was a $21.3 \mathrm{~m}$ by $21.3 \mathrm{~m}$ layout with a total air-conditioned floor area of $455 \mathrm{~m}^{2}$. The perimeter zone depth was $4.6 \mathrm{~m}$. The building operated from $6 \mathrm{am}$ to $7 \mathrm{pm}$ on weekdays only. The roof was constructed with built-up materials on a flat plywood deck, over an unventilated and unconditioned plenum, above a studded ceiling frame with fiberglass insulation (varying by vintage), and with a sheet of drywall beneath. Other major characteristics of the office prototypes are summarized in Table 2 [24]. 
The building was cooled and heated by five rooftop, constant-volume, packaged-single-zone systems, each one servicing a single zone. The systems were sized based on peak-cooling and -heating loads as determined by DOE-2, which allowed for peak loads to be met and for maximum savings to be calculated. Duct loads were simulated by specifying air leakage and temperature drop. An economizer was also implemented.

Specific building characteristics data were not available for office buildings in the GTA. Office characteristics were taken from previous research focusing on the effect of reflective roofs in eleven U.S. metropolitan areas [4] and Energy $\operatorname{Star}{ }^{\circledR}[27]$.

\section{Retail Store}

The retail store was modeled as a single-story non-directional building with a single zone, also in two construction vintages: pre-1980 and $1980+$. The floor plan was a $27.4 \mathrm{~m}$ by $27.4 \mathrm{~m}$ layout with $750 \mathrm{~m}^{2}$ of total air-conditioned floor area. The building operated from $8 \mathrm{am}$ to $9 \mathrm{pm}$ on weekdays and from 10am to $5 \mathrm{pm}$ on weekends and holidays. The roof was constructed with built-up materials on a flat plywood deck, over an unventilated and unconditioned plenum, above a studded ceiling frame with fiberglass insulation, and with a sheet of drywall beneath. Other major characteristics of the retail store prototypes are summarized in Table 2 [24].

The building was cooled and heated by a single rooftop, constant volume packaged-single-zone system. The system was sized based on peak cooling and heating loads as determined by DOE-2, which allowed for peak loads to be met and for maximum savings to be calculated. Duct loads were simulated by specifying air leakage and temperature drop. An economizer was also implemented.

Specific building characteristic data for retail store buildings in the GTA were not available. Retail store characteristics were taken from previous research focusing on the effect of reflective roofs in 11 U.S. metropolitan areas [4] and Energy $\operatorname{Star}{ }^{\circledR}[27]$.

\section{Solar-Reflective Roofs}

A solar-reflective roof is typically light in color and absorbs less sunlight than a conventional darkcolored roof. Less absorbed sunlight means a lower surface temperature, which directly reduces heat gain through the roof and air-conditioning demand. Typical values of albedo for low- and high-albedo roofs were selected to cover the wide range of commercially available roofing materials (shingles, tiles, membranes and coatings) and the effects of weathering and aging. These were obtained primarily from the Cool Roofing Materials Database [28], containing measured values of roof absorptance across the solar spectrum. 
For the sloped-roof residential sector, commercially available high-reflective materials are scarce. White asphalt shingles are available, but have a relatively low albedo of 0.25-0.27. White coatings can be applied to shingles or tiles to obtain an aged albedo of about 0.5. Some high-reflective white shingles are being developed, but are only in the prototype stage. Also, some reflective tiles are available. Conversely, high-reflective materials for the low-slope commercial sector are on the market. White acrylic, elastomeric and cementatious coatings can now be applied to built-up roofs to achieve an aged solarreflectance of 0.6 and likewise for white thermoplastic membranes. A "generic white" asphalt shingle has a laboratory tested initial albedo of 0.25 [28]. A "generic gray" asphalt shingle has a laboratory tested initial albedo of 0.22 , and the albedo of a green or brown shingle is about 0.12-0.15 [28].

The values of roof albedo were chosen to be 0.2 and 0.5 for residential roofs and 0.2 and 0.6 for commercial roofs, which represent low and high albedo materials. The long-wave thermal emittance of these materials was a uniform 0.9. We only accounted for the changes of the roof reflectance during the summer and did not model the effect of snow on the roof during the winter season. This assumption provides a good estimate of summertime saving potentials and slightly overestimates the wintertime heating penalties of the reflective roofs (i.e., both reflective and non-reflective roofs are covered by snow during winter).

Bretz and Akbari [29] have reported that the albedo of white-coated roof surfaces can degrade up to $20 \%$ over a period of several years as a result of weathering and accumulation of dirt and debris (microbial growth can contribute to degradation in humid climates), and by washing the roof, the albedo can be restored to $90-100 \%$ of the initial value. Note that rainfall can cleanse a roof and in most cases have the same effect as a thorough washing.

\section{Shade Trees}

Shade trees were modeled in DOE-2 as a box-shaped building shade with seasonal transmittance. ${ }^{1}$ The summertime transmittance was 0.1 for 1 April through 31 October and wintertime was 0.9 for the remainder of the year. The geometry of the modeled tree consisted of a square cross-sectional area of $21 \mathrm{~m}^{2}, 4.6 \mathrm{~m}$ by $4.6 \mathrm{~m}$, a depth of $3 \mathrm{~m}$, and a canopy height of $4.6 \mathrm{~m}$. They were placed outside the south and west walls near the windows (with $0.6 \mathrm{~m}$ of clearance from the building) in order to maximize the effect on the building-cooling load. The fully-grown trees shade a portion of the roof during low sun hours, but do not cover any of it during high sun hours. The number of shade trees modeled were 4, 8 and 10 for the residence, office, and retail store, respectively.

\footnotetext{
${ }^{1}$ The fraction of light that passes through the tree is the transmittance.
} 


\section{Wind-Shielding}

Trees shield the walls and portions of the roof from wind directly reducing wind speed, thus reducing outside air film conductance and wind-speed dependent infiltration. The tree-planting strategy consists in placing coniferous vegetation on the north side of a building to shield from cold northerly winds, and to locate deciduous foliage on the south and west sides.

The wind-shielding effect on cooling- and heating-energy use from a $20 \%$ increase in vegetation cover around buildings was modeled within DOE-2 by altering the three DOE-2 keywords: (1) SHIELDINGCOEFFICIENT, (2) TERRAIN-PAR1, and (3) TERRAIN-PAR2 [30]. The Shielding-Coefficient value is used in calculating the Sherman-Grimsrud infiltration. The coefficient modifies the wind speed term in the model to account for changes in wind pressure caused by local obstructions. DOE-2 assigns a Shielding Coefficient of 0.19 for "typical suburban shielding - Heavy shielding, obstructions around most of perimeter, buildings or trees within 30 feet in most directions" and a coefficient of 0.10 for "typical downtown shielding - Very heavy shielding, large obstructions surrounding perimeter within two house heights." The value of 0.19 representing typical suburban shielding was used for base simulations; this was altered to 0.17 [a $20 \%$ adjustment from 0.19 to 0.10 , i.e. $0.19-0.2 *(0.19-0.10)=0.17$ ]

The same methodology was used to modify the wind speed for terrain and space height effects at the building site using the keywords TERRAIN-PAR1 and TERRAIN-PAR2. Values of 0.85 and 0.20 representing rural area with low buildings and trees were altered to 0.81 and 0.21 (a 20\% adjustment from "rural" to "urban" areas as defined by DOE-2 [30]).

\section{Energy Simulations}

The DOE-2 model simulates energy use of a building for 8,760 hours of a year, using typical hourly weather data [31]. Using Toronto Weather Year for Energy Consumption (WYEC2) data, annual coolingand heating-energy use and peak-power demand were simulated for residential, office and retail store building prototypes, and savings were calculated for each HIR strategy. To estimate the effect of heatisland reduction measures on the ambient temperature, we used the PSU/NCAR MM5 mesoscale meteorological model to simulate changes in the temperature field over the GTA [32]. We then estimated changes in an average dry-bulb air temperature from 15 locations within the boundaries of the model over 72-hour winter (Jan 15-17) and summer (July 15-17) episodes. The changes in ambient temperature $(\Delta \mathrm{T})$ were then regressed as a function of solar intensity (I) (see Eq. 1).

$\Delta \mathrm{T}\left[{ }^{\circ} \mathrm{K}\right]=-0.0018 \mathrm{I}\left[\mathrm{W} / \mathrm{m}^{2}\right] \quad$ EQ. 1. 
Because $\Delta \mathrm{T}$ is solely a function of solar intensity, $\Delta \mathrm{T}$ is zero during hours without sunlight. Finally, we modified the standard WYEC2 weather data $\left(\mathrm{T}_{\text {modified }}=\mathrm{T}_{\text {standard }}+\Delta \mathrm{T}\right)$ to create modified temperature data for the building energy simulations. The rerun of the DOE-2 simulations with the modified weather data quantified the indirect effect of HIR measures on building-energy use.

In Table 3, cooling and heating degree-days (base $18.3^{\circ} \mathrm{C}$ ) and the maximum air temperature have been tallied monthly for both standard and modified WYEC2 weather data. The difference between the modified and the standard data is denoted by $\Delta \mathrm{T}$ in the table. Ambient cooling from urban fabric modification was observed mostly during June, July and August with 64, 106 and 91 fewer cooling degree-days during those months. The annual 324 cooling-degree-days were reduced by 45 and the annual heating-degree-days was reduced by 54. The greatest reduction in maximum ambient air temperature was simulated as $1.7^{\circ} \mathrm{K}$ from a high of $34^{\circ} \mathrm{C}$ in July.

Local residential and commercial electricity and natural gas rates were applied to the simulation results to obtain total annual energy use in dollars. Average commercial rates for electricity and natural gas consumption were available from a 1998 City of Toronto facility analysis [33] and were $\$ 0.084 / \mathrm{kWh}$ and $\$ 5.54 / \mathrm{GJ}\left(\$ 0.206 / \mathrm{m}^{3}\right)$. Specific residential rates were obtained by inspecting the monthly utility bill for a typical house [34]. Based on a comparison of Toronto Hydro Electric System rate schedules, we found that the residential and commercial electricity rate were essentially the same [35]. The gas rate was $\$ 10.84 /$ GJ. The price of gas has changed significantly over the last few years. To perform a preliminary analysis of the effect of the gas price on potential savings, we also calculated the net savings with a uniform price of $\$ 5.54 / \mathrm{GJ}$ for both residential and commercial buildings.

\section{Results of DOE-2.1E Energy Simulations}

The simulations provided estimates of annual cooling- and heating-electricity use $\left[\mathrm{kWh} / 100 \mathrm{~m}^{2}\right]$, annual heating natural gas use $\left[\mathrm{GJ} / 100 \mathrm{~m}^{2}\right]$ and cooling peak-power demand $\left[\mathrm{kW} / 100 \mathrm{~m}^{2}\right]$, all normalized per $100 \mathrm{~m}^{2}$ of flat roof area . From the simulations, the annual total expenditures for cooling and heating energy $\left[\$ / 100 \mathrm{~m}^{2}\right]$ could then be calculated using local energy prices. Using the base case as a reference, annual energy and peak-power savings were determined for each HIR strategy. The base expenditure and demand and savings are presented in Tables $4^{1}$ and 5. Table 4 shows the energy and demand savings in absolute terms $\left[\mathrm{kWh} / 100 \mathrm{~m}^{2}, \mathrm{GJ} / 100 \mathrm{~m}^{2} \& \mathrm{~kW} / 100 \mathrm{~m}^{2}\right]$, and Table 5 shows the dollar saving in with two prices for residential gas.

\footnotetext{
${ }^{1}$ Linear interpolation can be used to estimate savings or penalties for other net changes in roof reflectance $\left(\Delta \hat{\mathrm{a}}_{2}\right)$ than presented in the tables $\left(\Delta \hat{\mathrm{a}}_{1}\right)$ [4]. Therefore, these results can be simply adjusted by the ratio $\Delta \hat{\mathrm{a}}_{2} / \Delta \hat{\mathrm{a}}_{1}$ to obtain estimates for other reflective roof scenarios.
} 
The simulations predicted net annual energy savings of about 3-5\% from combined direct and indirect

effects $\left[17-22 \$ / 100 \mathrm{~m}^{2}\right.$ for old and $9 \$ / 100 \mathrm{~m}^{2}$ for new] in gas-heated single-family and row-house residences. This number increased to $10 \%$ for offices $\left[40 \$ / 100 \mathrm{~m}^{2}\right.$ for new and $100 \$ 1100 \mathrm{~m}^{2}$ for old] and $12 \%$ for retail buildings $\left[40 \$ / 100 \mathrm{~m}^{2}\right.$ for new and $100 \$ / 100 \mathrm{~m}^{2}$ for old]. Electric-heated units did not fair so well, where savings of $0-2 \%$ were simulated for residences and $5-9 \%$ for the office and retail buildings because the higher cost of electric heating than that of gas heating.

An annual natural gas deficit was found for all building types and in each HIR mitigation strategy with the exception of wind-shielding; wind-shielding reduced the heating requirements the buildings. The annual gas deficit for combined direct and indirect effects was $2-6 \$ / 100 \mathrm{~m}^{2}$ for residences, $11-12 \$ / 100 \mathrm{~m}^{2}$ for offices and only $0-3 \$ / 100 \mathrm{~m}^{2}$ for retails.

Simulated peak-power reduction was significant for all building types and strategies (wind-shielding was the exception). Combined direct and indirect peak-demand reduction in cooling electricity was $21-23 \%$ in residences and $13-16 \%$ in offices and retails. This translates into $0.57-0.61 \mathrm{~kW} / 100 \mathrm{~m}^{2}$ for pre-1980 residences, $0.33-0.40 \mathrm{~kW} / 100 \mathrm{~m}^{2}$ for $1980+$ residences, $0.60-1.13 \mathrm{~kW} / 100 \mathrm{~m}^{2}$ for old and new offices, and $0.36-0.71 \mathrm{~kW} / 100 \mathrm{~m}^{2}$ for old and new retails.

\section{Air-Conditioned Roof Area for the GTA}

The stock of air-conditioned residential, office and retail buildings in the GTA were estimated for both pre-1980 and 1980+ construction vintages and both natural gas and electricity heating fuels. The 1996 population for the GTA was 4,218,465 residing in 1,488,370 households [36].

The total roof area for the stock of residences with a/c was calculated from integrating data from Statistics Canada [36], ICLEI Energy Services [37], and NRCAN [22,38]. The residential stock was disaggregated into single-family, row-house (multi-family) and apartment structure types for pre-1980 and 1980+ construction vintages. The total residential air-conditioned roof area for the GTA was estimated to be $39.8 \mathrm{Mm}^{2}$ (77\% single-family, 20\% row-house and 3\% apartment) [24].

The total roof area for the stock of office buildings and retail stores with a/c was calculated for pre-1980 and 1980+ construction vintages from integrating data from the above residential sector estimates and from Konopacki et al. [4]. Office and retail air-conditioned roof area for the GTA was estimated to be $5.3 \mathrm{Mm}^{2}\left(1.9 \mathrm{Mm}^{2}\right.$ for offices and $3.4 \mathrm{Mm}^{2}$ for retail stores $)[24]$.

\section{Metropolitan-Area Estimates}

Metropolitan-wide potential annual electricity savings [GWh], annual natural gas deficit [PJ], and peak power avoided $[\mathrm{MW}]$ are presented in Table 6. Metropolitan-wide estimates of annual energy-use 
expenditure and savings [M\$] are presented in Table 7 with two prices for residential gas. With uniform gas prices for commercial and residential buildings, annual electricity savings of $\$ 12.6 \mathrm{M}$ less a $10 \%$ natural gas deficit combine for a potential rate-payer benefit of over $\$ 11 \mathrm{M}$. Of that total, about $88 \%$ derived from the direct effects, divided roughly equally among reflective roofs, shade trees, and windshielding, and the remainder (12\%) from the indirect effects of the cooler ambient air temperature. The residential sector accounts for over half (about 59\%) of the total savings, offices 13\% and retail stores $27 \%$. Savings from cool roofs were about $20 \%$, shade trees $30 \%$, wind-shielding of trees $37 \%$, and indirect effect $12 \%$. These results are highly sensitive to the price of gas. Assuming a residential gas price of $\$ 10.84 / \mathrm{GJ}$ (gas price during December 2001), the net annual savings are reduced to $\$ 10 \mathrm{M}$; about $78 \%$ resulted from wind-shielding, 16\% from shading by trees, and 5\% from cool roofs.

Potential annual electricity savings were estimated at about $150 \mathrm{GWh}$ or over $\$ 12 \mathrm{M}$, of which about $75 \%$ accrued from roofs and shade trees and only $2 \%$ from wind-shielding. The indirect effect from a modified urban fabric was $23 \%$. The savings distributed among buildings is similar to those cited above.

The potential annual natural gas deficit was estimated to be over 0.232 PJ or just under \$1-2M, with actual savings of over $\$ 4-8 \mathrm{M}$ from wind-shielding and a combined penalty of under \$3-7M. Residences accounted for about $94 \%$ of the gas deficit.

Potential peak-power avoidance was estimated at about 250MW with about $74 \%$ attributed to the direct effects (roofs about 24\%, shade trees $51 \%$ and wind-shielding a small negative fraction) and the remainder $(26 \%)$ to the indirect effect. About $83 \%$ of the avoided peak power resulted from the effects of the residences. The remainder was shared by offices (7\%) and retail stores $(9 \%)$.

\section{Discussion}

In this study, we focused on three building types (residential, office, and retail) that offer the highest potential savings for the GTA. HIR technologies are also very effective on other building types such as hospitals, schools, restaurants, grocery stores, etc. However, the potential savings from these other buildings only contribute a few percent additional savings for the entire GTA.

In reviewing the results of this analysis, the following should be considered:

1. Reflective roofs and shade trees reduce summer cooling-energy use and also potentially increase winter heating-energy use. The net savings (\$ savings in cooling energy use minus \$ penalties in heating-energy use) are highly sensitive to prices of cooling- and heating-energy fuels. In the residential building prototypes cooled and heated with electricity, we found that most of the coolingenergy savings are written off by the penalties in heating-energy use. Since reflective roofs and shade 
trees affect the energy performance of a building typically for 20-30 years, a better understanding of long-term trends in energy prices would lead to better estimates of savings potentials.

2. Trees affect the energy use of a building by shading and wind shielding. Our capabilities to simulate the shading effects of trees are typically more refined than simulating the wind-shielding effects. Future studies to investigate further the wind-shielding effects of trees on heating-energy use would improve the current estimates.

3. DOE-2 can underestimate the cooling-energy saving potentials of reflective roofs by as much as a factor of two. Hence, the saving potentials shown for reflective roofs should be considered as conservative. Furthermore, during the winter, some of the roofs are covered with snow. Hence, the heating penalties of reflective roofs are potentially overestimated. A few monitoring and demonstration projects at the GTA would lead to a better understanding of the actual saving potentials in the region.

4. Although the simulations were performed for office, retail store, and residential prototypes, the results are normalized by roof area for each prototype. These results can be used to estimate savings potentials in other building types. For instance, one can comfortably estimate savings for a hospital based on the results obtained for office buildings.

5. The total roof area for commercial buildings in the GTA was estimated using an approach based on the population and the residential roof area. A more direct estimate of the actual roof area for commercial buildings can improve the accuracy of the estimates.

6. The indirect savings potential was only a small fraction of total potential savings. Hence, for consideration of energy savings potential, reflective roofs and shade trees that save energy both directly and indirectly should be given a higher priority than reflective pavements that save energy only indirectly.

\section{Conclusion}

We simulated the potential of Heat Island Reduction (HIR) strategies (i.e., solar-reflective roofs, shade trees, wind-shielding, reflective pavements and urban vegetation) to reduce cooling-energy use in buildings in the Greater Toronto Area, Canada. The impact of both direct effect (reducing heat gain through the building shell) and indirect effect (reducing the ambient air temperature) was addressed.

For gas-heated residential prototypes, the simulations predicted annual total energy savings of about 3-5\% from combined direct and indirect effects $\left[17-22 \$ / 100 \mathrm{~m}^{2}\right.$ for old and $9 \$ / 100 \mathrm{~m}^{2}$ for new residences]. This number increased to $10 \%$ for offices $\left[40 \$ / 100 \mathrm{~m}^{2}\right.$ for new and $100 \$ 1100 \mathrm{~m}^{2}$ for old] and $12 \%$ for retail 
stores $\left[40 \$ / 100 \mathrm{~m}^{2}\right.$ for new and $100 \$ / 100 \mathrm{~m}^{2}$ for old]. Electrically-heated units did not fare so well, because the electric heating penalty is more expensive than that of gas. Savings of $0-2 \%$ were observed for these residences and 5-9\% for offices and retail stores.

An annual natural gas deficit was found for all building types and in each HIR strategy with the exception of wind-shielding; wind-shielding reduced the heating requirements of all buildings. The annual gas deficit for combined direct and indirect effects was $2-6 \$ / 100 \mathrm{~m}^{2}$ for residences, $11-12 \$ / 100 \mathrm{~m}^{2}$ for offices and only $0-3 \$ / 100 \mathrm{~m}^{2}$ for retails.

Simulated peak-power reduction was significant for all building types and strategies (wind-shielding was the exception). Combined direct and indirect peak-demand reduction in cooling electricity was $21-23 \%$ in residences and $13-16 \%$ in offices and retails. This translates into $0.57-0.61 \mathrm{~kW} / 100 \mathrm{~m}^{2}$ for pre-1980 residences, $0.33-0.40 \mathrm{~kW} / 100 \mathrm{~m}^{2}$ for $1980+$ residences, $0.60-1.13 \mathrm{~kW} / 100 \mathrm{~m}^{2}$ for old and new offices, and $0.36-0.71 \mathrm{~kW} / 100 \mathrm{~m}^{2}$ for old and new retails.

For the entire GTA, potential annual energy savings of over $\$ 11 \mathrm{M}$ (with uniform residential and commercial electricity and gas prices of $\$ 0.084 / \mathrm{kWh}$ and $\$ 5.54 / \mathrm{GJ}$ ) could be realized by rate-payers from the combined direct and indirect effects of HIR strategies. Of that total, about $88 \%$ was from the direct effect and $12 \%$ from the indirect effect of the cooler ambient air temperature. The residential sector accounts for over half (about 59\%) of the total savings, offices $13 \%$ and retail stores $27 \%$. Savings from cool roofs were about $20 \%$, shade trees $30 \%$, wind-shielding by trees $37 \%$, and indirect effects $12 \%$. These results were highly sensitive to the price of gas. Assuming a residential gas price of $\$ 10.84 / \mathrm{GJ}$ (gas price during December 2001), the net annual savings are reduced to $\$ 10 \mathrm{M}$; about $78 \%$ resulted from wind-shielding, 16\% from shading by trees, and 5\% from cool roofs.

Potential annual electricity savings were estimated at about $150 \mathrm{GWh}$ or over $\$ 12 \mathrm{M}$, of that about $75 \%$ accrued from roofs and shade trees and only $2 \%$ from wind-shielding. The indirect effect from a modified urban fabric was $23 \%$. The potential annual natural gas deficit was estimated to be over 0.23 PJ or just under $\$ 1-2 \mathrm{M}$, with actual savings of over $\$ 4-8 \mathrm{M}$ from wind-shielding and a combined penalty of under \$3-7M. Residences accounted for about $94 \%$ of the gas deficit.

Potential avoided peak-power was estimated at about 250MW, with about $74 \%$ attributed to direct and $26 \%$ to indirect effects. About $83 \%$ of the avoided peak power occurred in the residences and the rest was shared by offices $(7 \%)$ and retail stores $(9 \%)$.

By their nature, the results of this study are preliminary. Our objective was to perform a preliminary analysis and provide an estimate of potential energy and peak-demand savings from the implementation of HIR measures. We focused on three building types (residential, office, and retail) that offer the highest 
potential savings for the GTA, and these three building types constitute over $90 \%$ of the floor area of the total building stock in the GTA. The HIR technologies are also very effective in other building types such as hospitals, schools, restaurants, grocery stores, etc. However, the potential savings from these other buildings only contribute a few percent of additional savings for the entire metropolitan Toronto.

\section{Acknowledgement}

This work was supported by the Toronto Atmospheric Fund (TAF) under Contract No. BG01-150(00) and the Assistant Secretary for Energy Efficiency and Renewable Energy, Building Technologies, of the U.S. Department of Energy (DOE) under contract No. DE-AC03-76SF00098. The authors acknowledge the support and guidance of Eva Ligeti (TAF) throughout the completion of the project.

\section{References}

[1] Akbari, H. and H. Taha. The Impact of Trees and White Surfaces on Residential Heating and Cooling Energy Use in Four Canadian Cities. Energy 1992; 17:141-150.

[2] Akbari, H., M. Pomerantz, and H. Taha. Cool Surfaces and Shade Trees to Reduce Energy Use and Improve Air Quality in Urban Areas. Solar Energy 2001; 70(3):295-310.

[3] Jessup, P. Private communication. Toronto Atmospheric Fund, Toronto, Canada, 2000.

[4] Konopacki, S., H. Akbari, M. Pomerantz, S. Gabersek, and L. Gartland. Cooling Energy Savings Potential of Light-Colored Roofs for Residential and Commercial Buildings in 11 US Metropolitan Areas. Report LBNL-39433. Berkeley, CA: Lawrence Berkeley National Laboratory, 1997.

[5] Konopacki, S. and H. Akbari. Energy Savings Calculations for Heat Island Reduction Strategies in Baton Rouge, Sacramento and Salt Lake City. Report LBNL-42890. Berkeley, CA: Lawrence Berkeley National Laboratory, 2000.

[6] Konopacki, S. and H. Akbari. Energy Savings for Heat Island Reduction Strategies in Chicago and Houston (Including Updates for Baton Rouge, Sacramento, and Salt Lake City). Report LBNL49638. Berkeley, CA: Lawrence Berkeley National Laboratory, 2002.

[7] Konopacki, S. and H. Akbari. Simulated Impact of Roof Surface Solar Absorptance, Attic, and Duct Insulation on Cooling and Heating Energy Use in Single-Family New Residential Buildings. Report LBNL-41834. Berkeley, CA: Lawrence Berkeley National Laboratory, 1998.

[8] Akbari, H., S. Konopacki, C. Eley, B. Wilcox, M. Van Geem, and D. Parker. Calculations for Reflective Roofs in Support of Standard 90.1. ASHRAE Transactions 1998; 104(1): 984-995. 
[9] Parker, D., J. Huang, S. Konopacki, L. Gartland, J. Sherwin, and L. Gu. Measured and Simulated Performance of Reflective Roofing Systems in Residential Buildings. ASHRAE Transactions 1998; 104(1): 963-975.

[10] Taha, H., S. Konopacki, and S. Gabersek. Modeling the Meteorological and Energy Effects of Urban Heat Islands and Their Mitigation: a 10 Region Study. Report LBNL-39335. Berkeley, CA: Lawrence Berkeley National Laboratory, 1996.

[11] Konopacki, S. and H. Akbari. Measured Energy Savings and Demand Reduction from a Reflective Roof Membrane on a Large Retail Store in Austin. Report LBNL-47149. Berkeley, CA: Lawrence Berkeley National Laboratory, 2001.

[12] Akbari, H. and L. Rainer. Measured Energy Savings from the Application of Reflective Roofs in 3 AT\&T Regeneration Buildings. Report LBNL-47075. Berkeley, CA: Lawrence Berkeley National Laboratory, 2000.

[13] Konopacki, S., H. Akbari, L. Gartland, and L. Rainer. Demonstration of Energy Savings of Cool Roofs. Report LBNL-40673. Berkeley, CA: Lawrence Berkeley National Laboratory, 1998.

[14] Akbari, H., S. Bretz, D. Kurn, and J. Hanford. Peak Power and Cooling Energy Savings of HighAlbedo Roofs. Energy and Buildings 1997; 25:117-126.

[15] Hildebrandt, E., W. Bos, and R. Moore. Assessing the Impacts of White Roofs on Building Energy Loads. ASHRAE Technical Data Bulletin 1998; 14(2).

[16] Parker, D. and K. Sheinkopf. Cool Home Features Bring Peak Energy Savings. Home Energy 1999; 16:22-27.

[17] Parker, D., J. Sonne, and J. Sherwin. Demonstration of Cooling Savings of Light Colored Roof Surfacing in Florida Commercial Buildings: Retail Strip Mall. Cocoa, Fl: Florida Solar Energy Center Report FSEC-CR-964-97, 1997.

[18] Parker, D., J. Sherwin, and J. Sonne. Measured Performance of a Reflective Roofing System in a Florida Commercial Building. ASHRAE Technical Data Bulletin 1998; 14(2).

[19] Akridge, J. High-Albedo Roof Coatings - Impact on Energy Consumption. ASHRAE Technical Data Bulletin 1998; 14(2).

[20] Boutwell, C. and Y. Salinas. Building for the Future - Phase I: An Energy Saving Materials Research Project. Oxford: Mississippi Power Co., Rohm and Haas Co. and the University of Mississippi, 1986. 
[21] Akbari, H., D. Kurn, S. Bretz, and J. Hanford. Peak Power and Cooling Energy Savings of Shade Trees. Energy and Buildings 1997; 25:139-148.

[22] Natural Resources Canada (NRCAN). Toronto Survey of 1361 Homes. Office of Energy Efficiency, Ottawa, Ontario, 2001.

[23] Natural Resource Canada (NRCAN). http://oee.nrcan.gc.ca/english/newhouses_r2000.cfm, R-2000 Program. Office of Energy Efficiency, 2001.

[24] Konopacki, S. and H. Akbari. Energy Impacts of Heat Island Reduction Strategies in Toronto, Canada. Report LBNL-49172. Berkeley, CA: Lawrence Berkeley National Laboratory, 2001.

[25] Sherman, M., D. Wilson and D. Kiel. Variability in Residential Air Leakage. Measured Air Leakage in Buildings ASTM STP-904. Philadelphia, PA, 1986.

[26] Henderson, H., D. Parker, and Y. J. Huang. Improving DOE-2's RESYS Routine: User defined functions to provide more accurate part load energy use and humidity predictions. Report LBNL46304. Berkeley, CA: Lawrence Berkeley National Laboratory, 2000.

[27] U. S. Department of Energy. http://www.eren.doe.gov/buildings/heatcool_cenair.html. Choosing or Upgrading Your Central Air-conditioner. Office of Building Technology, State and Community Programs, 2001.

[28] Cool Roofing Materials Database. http://eetd.lbl.gov/coolroof. Berkeley, CA: Lawrence Berkeley National Laboratory, 2001.

[29] Bretz, S. and H. Akbari. Long-Term Performance of High-Albedo Roof Coatings. Energy and Buildings 1997; 25:159-167.

[30] Winklemann, F., B. Birdsall, W. Buhl, K. Ellington, and A. Erdem. DOE-2 Supplement Version 2.1E. Report LBNL-34947. Berkeley, CA: Lawrence Berkeley National Laboratory, 1993.

[31] Building Energy Simulation Group. Overview of the DOE-2 Building Energy Analysis Program, Version 2.1D. Report LBL-19735, Rev. 1. Berkeley, CA: Lawrence Berkeley National Laboratory, 1990.

[32] Grell, G., J. Dudhia, and D. Stauffer. A Description of the Fifth-Generation Penn State/NCAR Mesoscale Model (MM5). Technical Note NCAR/TN-398 + STR. Boulder, CO: National Center for Atmospheric Research, 1994. 
[33] International Council for Local Environmental Initiatives Energy Services (ICLEI). Summary Report Opportunities for Budget Cost Savings in the City of Toronto's Corporate Facilities - Technical Reference: Data and Analysis. Toronto, Canada, 2001.

[34] Ligeti, E. Private communication. Obtained copy of an electricity and gas utility bills for a singlefamily residence. Toronto Atmospheric Fund, Toronto, Canada, 2002.

[35] Toronto Hydro Electric System. Rates. WWW. torontohydro.com/electricsystem/residential/rates.htm, 2001.

[36] Statistics Canada. http://www.statcan.ca/, 1996.

[37] International Council for Local Environmental Initiatives Energy Services (ICLEI). Realizing Toronto's Target for Greenhouse Gas Emission Reductions - Current Trends and Outlook. Torrie Smith Associates. Toronto, Ontario, 1997.

[38] Natural Resources Canada (NRCAN). 1993 Survey of Household Energy Use. Energy Publications. Ottawa, Ontario, 1995. 
Table 1. Single-Family Residence and Row-House. Prototypical Building Description for the Greater Toronto Area

\begin{tabular}{|c|c|c|c|c|c|}
\hline \multirow{2}{*}{ 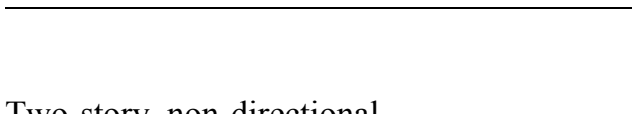 } & \multicolumn{3}{|c|}{ Single-Family Residence } & \multicolumn{2}{|c|}{ Row House } \\
\hline & Pre-1980 & $1980+$ & R-2000 & Pre-1980 & $1980+$ \\
\hline $\begin{array}{l}\text { Two-story, non-directional } \\
\text { Roof \& floor area }\left(\mathrm{m}^{2}\right)\end{array}$ & $93 / 185$ & $112 / 223$ & $93 / 185$ & $56 / 112$ & $46 / 93$ \\
\hline \multicolumn{6}{|l|}{$\begin{array}{l}\text { Zones } \\
\text { living (conditioned) } \\
\text { attic (unconditioned) } \\
\text { basement (unconditioned) }\end{array}$} \\
\hline Roof insulation $\left(\mathrm{m}^{2} \mathrm{~K} / \mathrm{W}\right)$ & $\begin{array}{c}3.34 \\
(\mathrm{R}-19)\end{array}$ & $\begin{array}{c}5.28 \\
(\mathrm{R}-30)\end{array}$ & $\begin{array}{c}6.69 \\
(\mathrm{R}-38)\end{array}$ & $\begin{array}{c}2.29 \\
(\mathrm{R}-13)\end{array}$ & $\begin{array}{c}5.28 \\
(\mathrm{R}-30)\end{array}$ \\
\hline \multicolumn{6}{|l|}{$\begin{array}{l}\text { Wall construction } \\
\text { brick exterior } \\
\text { wood frame }\end{array}$} \\
\hline insulation $\left(\mathrm{m}^{2} \mathrm{~K} / \mathrm{W}\right)$ & $\begin{array}{c}1.23 \\
(\mathrm{R}-7)\end{array}$ & $\begin{array}{c}2.46 \\
(\mathrm{R}-14)\end{array}$ & $\begin{array}{c}3.52 \\
(\mathrm{R}-20)\end{array}$ & $\begin{array}{l}1.06 \\
(\mathrm{R}-6)\end{array}$ & $\begin{array}{c}2.64 \\
(\mathrm{R}-15)\end{array}$ \\
\hline drywall interior & & & & & \\
\hline $\begin{array}{l}\text { Windows } \\
\text { clear with operable shades }\end{array}$ & $<$ & $\ldots$ & low- $\varepsilon$ & $-\ldots$ & $\ldots$ \\
\hline $\begin{array}{l}\text { number of panes } \\
\text { window to wall ratio }\end{array}$ & \multicolumn{3}{|c|}{ <------------ 0.08 ---------- > } & \multicolumn{2}{|c|}{$<----0.11$---- > } \\
\hline \multicolumn{6}{|l|}{ Fractional leakage area $\left(\mathrm{cm}^{2} / \mathrm{m}^{2}\right)$} \\
\hline Living & 2.8 & 1.4 & 1 & 2.8 & 0.7 \\
\hline Attic & 5.6 & 2.8 & 2 & 6.2 & 2.1 \\
\hline \multicolumn{6}{|l|}{$\begin{array}{l}\text { Cooling equipment } \\
\text { central a/c, air-cooled }\end{array}$} \\
\hline energy efficiency ratio (EER) & 8 & 10 & 12 & 8 & 10 \\
\hline capacity $(\mathrm{MJ} / \mathrm{h})$ & 38.0 & 31.7 & 25.3 & 38.0 & 31.7 \\
\hline $\begin{array}{l}\text { cooling setpoint }\left({ }^{\circ} \mathrm{C}\right) \\
\text { natural ventilation available }\end{array}$ & $<--------$ & -------- & $--25.6--$ & ----------- & $---->$ \\
\hline \multicolumn{6}{|l|}{ Heating equipment } \\
\hline $\begin{array}{l}\text { 1) central forced air gas furnace } \\
\text { efficiency }(\%)\end{array}$ & 82 & 85 & 85 & 81 & 92 \\
\hline capacity $(\mathrm{MJ} / \mathrm{h})$ & 79.1 & 63,3 & 52.8 & 42.2 & 38.0 \\
\hline heating setpoint $\left({ }^{\circ} \mathrm{C}\right)$ & \multirow{2}{*}{\multicolumn{5}{|c|}{ 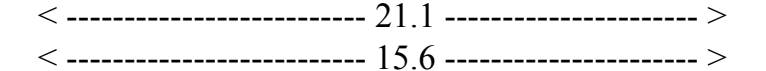 }} \\
\hline $11 \mathrm{pm}-7$ am setback $\left({ }^{\circ} \mathrm{C}\right)^{*}$ & & & & & \\
\hline 2) electric & \multicolumn{3}{|c|}{ central electric heat pump } & \multirow{2}{*}{\multicolumn{2}{|c|}{$\begin{array}{l}\text { resistance } \\
\text { N/A }\end{array}$}} \\
\hline heating season performance factor (HSFP) & 5 & 7 & 8 & & \\
\hline
\end{tabular}

* Although many houses may not use a heating setback, assuming a setback only affects the base heating energy use and not the potential heating penalties. 
Table 2. Office and Retail Store Prototypical Building Description for the Greater Toronto Area

\begin{tabular}{|c|c|c|c|c|}
\hline & \multicolumn{2}{|c|}{ Office } & \multicolumn{2}{|c|}{ Retail Store } \\
\hline & Pre-1980 & $1980+$ & Pre-1980 & $1980+$ \\
\hline $\begin{array}{l}\text { Single-Story, non-directional } \\
\text { roof \& floor area }\left(\mathrm{m}^{2}\right)\end{array}$ & \multicolumn{2}{|c|}{455} & \multicolumn{2}{|c|}{750} \\
\hline \multicolumn{5}{|l|}{$\begin{array}{l}\text { Zones: } 5 \text { zones (conditioned) } \\
\text { plenum (unconditioned) }\end{array}$} \\
\hline Ceiling insulation $\left(\mathrm{m}^{2} \mathrm{~K} / \mathrm{W}\right)$ & $\begin{array}{c}3.34 \\
(\mathrm{R}-19)\end{array}$ & $\begin{array}{c}5.2 \\
(\mathrm{R}-30)\end{array}$ & $\begin{array}{c}3.34 \\
(\mathrm{R}-19)\end{array}$ & $\begin{array}{c}5.28 \\
(\mathrm{R}-30)\end{array}$ \\
\hline \multicolumn{5}{|l|}{$\begin{array}{l}\text { Wall construction } \\
\text { brick exterior } \\
\text { wood frame }\end{array}$} \\
\hline insulation $\left(\mathrm{m}^{2} \mathrm{~K} / \mathrm{W}\right)$ & $\begin{array}{l}1.06 \\
(\mathrm{R}-6)\end{array}$ & $\begin{array}{c}2.29 \\
(\mathrm{R}-13)\end{array}$ & $\begin{array}{c}0.70 \\
(\mathrm{R}-4)\end{array}$ & $\begin{array}{c}2.29 \\
(\mathrm{R}-13)\end{array}$ \\
\hline drywall & & & & \\
\hline $\begin{array}{l}\text { Windows } \\
\text { clear with operable shades } \\
\text { number of panes } \\
\text { window to wall ratio }\end{array}$ & 1 & 2 & 1 & $.17^{2}$ \\
\hline $\begin{array}{l}\text { Cooling equipment } \\
\text { packaged a/c, air-cooled }\end{array}$ & 8 & 10 & 8 & 10 \\
\hline \multicolumn{5}{|l|}{ Heating equipment } \\
\hline $\begin{array}{l}\text { efficiency (\%) } \\
\text { (2) electric heat pump }\end{array}$ & 70 & 74 & 70 & 74 \\
\hline heating season performance factor (HSPF) & 5 & 7 & 5 & 7 \\
\hline $\begin{array}{l}\text { Distribution } \\
\text { constant-volume forced air system } \\
\text { economizer }\end{array}$ & fixed & temperature & fixed & temperature \\
\hline duct leakage $(\%)$ & 20 & 10 & 20 & 10 \\
\hline duct temperature drop $\left({ }^{\circ} \mathrm{C}\right)$ & 1.1 & 0.6 & 3 & 1 \\
\hline \multicolumn{5}{|l|}{ Thermostat } \\
\hline weekday operation & \multicolumn{2}{|c|}{$6 \mathrm{am}-7 \mathrm{pm}$} & \multicolumn{2}{|c|}{$6 \mathrm{am}-7 \mathrm{pm}$} \\
\hline weekend operation & \multirow{2}{*}{\multicolumn{2}{|c|}{$\begin{array}{l}\text { setback } \\
25.6\end{array}$}} & \multicolumn{2}{|c|}{$10 \mathrm{am}-5 \mathrm{pm}$} \\
\hline cooling setpoint $\left({ }^{\circ} \mathrm{C}\right)$ & & & \multicolumn{2}{|c|}{25.6} \\
\hline heating setpoint $\left({ }^{\circ} \mathrm{C}\right)$ & \multicolumn{2}{|c|}{$\begin{array}{l}25.6 \\
21.1\end{array}$} & & 1.1 \\
\hline \multicolumn{5}{|l|}{ Interior load } \\
\hline infiltration (air-change/hour) & \multicolumn{2}{|c|}{0.5} & \multicolumn{2}{|c|}{0.5} \\
\hline lighting $\left(\mathrm{W} / \mathrm{m}^{2}\right)$ & 20.4 & 15.1 & 25.8 & 18.3 \\
\hline equipment $\left(\mathrm{W} / \mathrm{m}^{2}\right)$ & 18.3 & 16.1 & 7.5 & 6.5 \\
\hline occupants & \multicolumn{2}{|r|}{25} & \multicolumn{2}{|r|}{16} \\
\hline
\end{tabular}


Table 3. Standard and modified Toronto WYEC2 weather data with cooling- and heating- degree-days and maximum air temperature tallied monthly $\left(\Delta \mathrm{T}=\mathrm{T}_{\text {modified }}-\mathrm{T}_{\text {standard }}\right)$.

\begin{tabular}{|c|c|c|c|c|c|c|}
\hline \multirow[b]{2}{*}{ month } & \multicolumn{2}{|c|}{$\begin{array}{c}\text { cooling degree-days } \\
\text { [base } 18.3^{\circ} \mathrm{C} \text { ] }\end{array}$} & \multicolumn{2}{|c|}{$\begin{array}{c}\text { heating degree-days } \\
\text { [base } 18.3^{\circ} \mathrm{C} \text { ] }\end{array}$} & \multicolumn{2}{|c|}{ maximum air temperature } \\
\hline & standard & $\Delta$ & standard & $\Delta$ & Standard $\left[{ }^{\circ} \mathrm{C}\right]$ & $\Delta[\mathrm{K}]$ \\
\hline January & 0 & 0 & 750 & 3 & 7 & 0.0 \\
\hline February & 0 & 0 & 671 & 5 & 5 & 0.0 \\
\hline March & 0 & 0 & 577 & 8 & 18 & -0.6 \\
\hline April & 2 & -1 & 359 & 11 & 24 & -1.1 \\
\hline May & 29 & -5 & 209 & 7 & 30 & -1.1 \\
\hline June & 64 & -10 & 68 & 9 & 33 & -1.1 \\
\hline July & 106 & -13 & 28 & 1 & 34 & -1.7 \\
\hline August & 91 & -11 & 40 & 1 & 32 & -0.6 \\
\hline September & 32 & -5 & 121 & 3 & 28 & -0.6 \\
\hline October & 1 & 0 & 269 & 6 & 21 & -0.6 \\
\hline November & 0 & 0 & 444 & 3 & 17 & -0.6 \\
\hline December & 0 & 0 & 662 & 2 & 8 & 0.0 \\
\hline Total & 324 & -45 & 4198 & 54 & & \\
\hline
\end{tabular}

Note: Maximum standard ambient air temperature and maximum modified temperature decrease are nonconcurrent. 
Table 4. Simulated cooling and heating annual base energy use and savings [electricity: $\mathrm{kWh} /\left(100 \mathrm{~m}^{2}\right)$, gas: $\left.\mathrm{GJ} /\left(100 \mathrm{~m}^{2}\right)\right]$, and peak-power demand and savings $\left[\mathrm{kW} /\left(100 \mathrm{~m}^{2}\right)\right]$ from Heat Island Reduction strategies for prototype residential and commercial buildings. Direct savings are from the use of solarreflective roofs, strategic placement of deciduous shade trees and wind-shielding vegetation, and indirect savings include the effect of reduced ambient air temperature from a modified urban fabric.

\begin{tabular}{|c|c|c|c|c|c|c|c|c|}
\hline \multirow{3}{*}{$\begin{array}{c}\text { building type } \\
\& \\
\text { mitigation strategy }\end{array}$} & \multicolumn{4}{|c|}{ gas heat } & \multirow{2}{*}{\multicolumn{2}{|c|}{$\begin{array}{c}\text { electric heat } \\
\text { electricity }\left[\mathrm{kWh} / 100 \mathrm{~m}^{2}\right]\end{array}$}} & \multirow{2}{*}{\multicolumn{2}{|c|}{$\begin{array}{l}\text { gas \& electric heat } \\
\text { peak power }\left[\mathrm{kW} / 100 \mathrm{~m}^{2}\right]\end{array}$}} \\
\hline & \multicolumn{2}{|c|}{ electricity $\left[\mathrm{kWh} / 100 \mathrm{~m}^{2}\right]$} & \multicolumn{2}{|c|}{ gas $\left[G J / 100 m^{2}\right]$} & & & & \\
\hline & Pre-1980 & $1980+$ & Pre-1980 & $1980+$ & Pre-1980 & $1980+$ & Pre-1980 & $1980+$ \\
\hline \multicolumn{9}{|l|}{ Residence: Single-Family } \\
\hline Energy use \& demand & 1057 & 629 & 75.0 & 49.3 & 14785 & 8391 & 2.70 & 1.71 \\
\hline \multicolumn{9}{|l|}{ Savings } \\
\hline reflective roof savings & 94 & 52 & -0.9 & -0.5 & -62 & -20 & 0.12 & 0.08 \\
\hline shade tree savings & 133 & 74 & -1.1 & -0.7 & -24 & -8 & 0.32 & 0.18 \\
\hline wind shield savings & -32 & -25 & 2.5 & 1.2 & 379 & 134 & 0.00 & -0.02 \\
\hline indirect savings & 88 & 51 & -0.8 & -0.5 & -100 & -59 & 0.13 & 0.09 \\
\hline combined savings & 283 & 152 & -0.2 & -0.6 & 193 & 47 & 0.57 & 0.33 \\
\hline \multicolumn{9}{|l|}{ Residence: R-2000 } \\
\hline Energy use \& demand & $\mathrm{n} / \mathrm{a}$ & 440 & $\mathrm{n} / \mathrm{a}$ & 307.0 & $\mathrm{n} / \mathrm{a}$ & 5737 & $\mathrm{n} / \mathrm{a}$ & 1.27 \\
\hline \multicolumn{9}{|l|}{ Savings } \\
\hline reflective roof savings & $\mathrm{n} / \mathrm{a}$ & 29 & $\mathrm{n} / \mathrm{a}$ & -5.0 & $\mathrm{n} / \mathrm{a}$ & -33 & $\mathrm{n} / \mathrm{a}$ & 0.05 \\
\hline shade tree savings & $\mathrm{n} / \mathrm{a}$ & 57 & $\mathrm{n} / \mathrm{a}$ & -5.0 & $\mathrm{n} / \mathrm{a}$ & -9 & $\mathrm{n} / \mathrm{a}$ & 0.17 \\
\hline wind shield savings & $\mathrm{n} / \mathrm{a}$ & -20 & $\mathrm{n} / \mathrm{a}$ & 6.0 & $\mathrm{n} / \mathrm{a}$ & 75 & $\mathrm{n} / \mathrm{a}$ & 0.00 \\
\hline indirect savings & $\mathrm{n} / \mathrm{a}$ & 36 & $\mathrm{n} / \mathrm{a}$ & -4.0 & $\mathrm{n} / \mathrm{a}$ & -39 & $\mathrm{n} / \mathrm{a}$ & 0.02 \\
\hline combined savings & $\mathrm{n} / \mathrm{a}$ & 101 & $\mathrm{n} / \mathrm{a}$ & -8.0 & $\mathrm{n} / \mathrm{a}$ & -5 & $\mathrm{n} / \mathrm{a}$ & 0.25 \\
\hline \multicolumn{9}{|l|}{ Residence: Row-House } \\
\hline Energy use \& demand & 1277 & 643 & 70.6 & 32.8 & 18509 & 8393 & 3.01 & 1.87 \\
\hline \multicolumn{9}{|l|}{ Savings } \\
\hline reflective roof savings & 113 & 52 & -1.1 & -0.4 & -111 & -60 & 0.16 & 0.09 \\
\hline shade tree savings & 127 & 75 & -0.8 & -0.5 & -34 & -11 & 0.29 & 0.22 \\
\hline wind shield savings & -18 & -13 & 1.1 & 0.3 & 194 & 45 & -0.02 & -0.01 \\
\hline indirect savings & 82 & 49 & -0.7 & -0.3 & -138 & -49 & 0.18 & 0.10 \\
\hline combined savings & 305 & 164 & -1.6 & -0.8 & -90 & -75 & 0.61 & 0.40 \\
\hline \multicolumn{9}{|l|}{ Office } \\
\hline Energy use \& demand & 7276 & 3842 & 57.3 & 27.5 & 16934 & 8108 & 7.12 & 4.20 \\
\hline \multicolumn{9}{|l|}{ Savings } \\
\hline reflective roof savings & 388 & 160 & -0.5 & -0.5 & 273 & 60 & 0.26 & 0.14 \\
\hline shade tree savings & 637 & 260 & -0.9 & -0.8 & 485 & 129 & 0.43 & 0.23 \\
\hline wind shield savings & -36 & -1 & 0.6 & 0.5 & 88 & 96 & 0.02 & 0.01 \\
\hline indirect savings & 271 & 164 & -0.3 & -0.4 & 160 & 64 & 0.42 & 0.23 \\
\hline combined savings & 1260 & 583 & -1.2 & -1.3 & 1007 & 350 & 1.13 & 0.60 \\
\hline \multicolumn{9}{|l|}{ Retail Store } \\
\hline Energy use \& demand & 7493 & 3356 & 31.1 & 10.1 & 12733 & 4944 & 4.90 & 2.63 \\
\hline \multicolumn{9}{|l|}{ Savings } \\
\hline reflective roof savings & 522 & 200 & -0.5 & -0.6 & 429 & 102 & 0.26 & 0.14 \\
\hline shade tree savings & 439 & 172 & -0.2 & -0.2 & 423 & 146 & 0.19 & 0.10 \\
\hline wind shield savings & -42 & -13 & 1.1 & 0.8 & 138 & 111 & 0.02 & 0.01 \\
\hline indirect savings & 258 & 133 & -0.3 & -0.3 & 179 & 82 & 0.24 & 0.11 \\
\hline combined savings & 1177 & 492 & 0.0 & -0.3 & 1170 & 442 & 0.71 & 0.36 \\
\hline
\end{tabular}


Table 5. Simulated cooling and heating annual base expenditures and savings $\left[\$ /\left(100 \mathrm{~m}^{2}\right)\right]$ from Heat Island Reduction strategies for prototype residential and commercial buildings. The numbers in parentheses show \% savings. Direct savings are from the use of solar-reflective roofs, strategic placement of deciduous shade trees and wind-shielding vegetation, and indirect savings include the effect of reduced ambient air Temperature from a modified urban fabric.

\begin{tabular}{|c|c|c|c|c|c|c|c|c|c|c|c|c|c|c|c|}
\hline \multirow{3}{*}{$\begin{array}{c}\text { building type } \\
\& \\
\text { mitigation strategy }\end{array}$} & \multicolumn{7}{|c|}{ Residential gas price of $\$ 5.54 / G J$} & \multicolumn{8}{|c|}{ Residential gas price of $\$ 10.84 / G J$} \\
\hline & \multicolumn{3}{|c|}{ gas heat } & \multicolumn{4}{|c|}{ electric heat } & \multicolumn{4}{|c|}{ gas heat } & \multicolumn{4}{|c|}{ electric heat } \\
\hline & Pre & e-1980 & $1980+$ & Pre- & -1980 & & $80+$ & Pre- & -1980 & & $80+$ & Pre- & 1980 & 198 & $30+$ \\
\hline \multicolumn{16}{|l|}{ Residence: Single-Family } \\
\hline Base energy expenditure & 504 & & 325 & 1242 & & 705 & & 898 & & 584 & & 1242 & & 705 & \\
\hline \multicolumn{16}{|l|}{ Savings } \\
\hline reflective roof savings & 2.5 & $(0.5)$ & $1.5(0.5)$ & -5.2 & $(-0.4)$ & -1.7 & $(-0.2)$ & -2.5 & $(-0.3)$ & -1.1 & $(-0.2)$ & -5.2 & $(-0.4)$ & -1.7 & $(-0.2)$ \\
\hline shade tree savings & 5.6 & $(1.1)$ & $2.0(0.6)$ & -2.0 & $(-0.2)$ & -0.7 & $(-0.1)$ & 0.3 & $(0.0)$ & -2.0 & $(-0.3)$ & -2.0 & $(-0.2)$ & -0.7 & $(-0.1)$ \\
\hline wind shield savings & 11.6 & $(2.3)$ & $4.4 \quad(1.4)$ & 31.8 & $(2.6)$ & 11.2 & $(1.6)$ & 25.1 & $(2.8)$ & 10.6 & $(1.8)$ & 31.8 & $(2.6)$ & 11.2 & (1.6) \\
\hline indirect savings & 2.7 & $(0.5)$ & $1.3(0.4)$ & -8.4 & $(-0.7)$ & -5.0 & $(-0.7)$ & -1.7 & $(-0.2)$ & -1.6 & $(-0.3)$ & -8.4 & $(-0.7)$ & -5.0 & $(-0.7)$ \\
\hline combined savings & 22.5 & $(4.5)$ & $9.3(2.8)$ & 16.2 & $(1.3)$ & 3.9 & $(0.6)$ & 21.2 & $(2.4)$ & 5.9 & $(1.0)$ & 16.2 & $(1.3)$ & 3.9 & $(0.6)$ \\
\hline \multicolumn{16}{|l|}{ Residence: R-2000 } \\
\hline Base energy expenditure & $\mathrm{n} / \mathrm{a}$ & & 216 & $\mathrm{n} / \mathrm{a}$ & & 482 & & $\mathrm{n} / \mathrm{a}$ & & 386 & & $\mathrm{n} / \mathrm{a}$ & & 482 & \\
\hline \multicolumn{16}{|l|}{ Savings } \\
\hline reflective roof savings & $\mathrm{n} / \mathrm{a}$ & & $-0.3(-0.1)$ & $\mathrm{n} / \mathrm{a}$ & & -2.8 & $(-0.6)$ & $\mathrm{n} / \mathrm{a}$ & & -2.9 & $(-0.8)$ & $\mathrm{n} / \mathrm{a}$ & & -2.8 & $(-0.6)$ \\
\hline shade tree savings & $\mathrm{n} / \mathrm{a}$ & & $1.7(0.8)$ & $\mathrm{n} / \mathrm{a}$ & & -0.7 & $(-0.2)$ & $\mathrm{n} / \mathrm{a}$ & & -1.3 & $(-0.3)$ & $\mathrm{n} / \mathrm{a}$ & & -0.7 & $(-0.2)$ \\
\hline wind shield savings & $\mathrm{n} / \mathrm{a}$ & & $1.5(0.7)$ & $\mathrm{n} / \mathrm{a}$ & & 6.3 & $(1.3)$ & $\mathrm{n} / \mathrm{a}$ & & 4.6 & $(1.2)$ & $\mathrm{n} / \mathrm{a}$ & & 6.3 & (1.3) \\
\hline indirect savings & $\mathrm{n} / \mathrm{a}$ & & $0.8 \quad(0.4)$ & $\mathrm{n} / \mathrm{a}$ & & -3.3 & $(-0.7)$ & $\mathrm{n} / \mathrm{a}$ & & -1.3 & $(-0.3)$ & $\mathrm{n} / \mathrm{a}$ & & -3.3 & $(-0.7)$ \\
\hline combined savings & $\mathrm{n} / \mathrm{a}$ & & $3.7(1.7)$ & $\mathrm{n} / \mathrm{a}$ & & -0.5 & $(-0.1)$ & $\mathrm{n} / \mathrm{a}$ & & -0.9 & $(-0.2)$ & $\mathrm{n} / \mathrm{a}$ & & -0.5 & $(-0.1)$ \\
\hline \multicolumn{16}{|l|}{ Residence: Row-House } \\
\hline Base energy expenditure & 498 & & 236 & 1555 & & 705 & & 868 & & 408 & & 1555 & & 705 & \\
\hline \multicolumn{16}{|l|}{ Savings } \\
\hline reflective roof savings & 3.4 & $(0.7)$ & $1.9(0.8)$ & -9.3 & $(-0.6)$ & -5.1 & $(-0.7)$ & -2.3 & $(-0.3)$ & -0.4 & $(-0.1)$ & -9.3 & $(-0.6)$ & -5.1 & $(-0.7)$ \\
\hline shade tree savings & 5.8 & $(1.2)$ & $3.6(1.5)$ & -2.9 & $(-0.2)$ & -0.9 & $(-0.1)$ & 1.2 & $(0.1)$ & 1.1 & $(0.3)$ & -2.9 & $(-0.2)$ & -0.9 & $(-0.1)$ \\
\hline wind shield savings & 4.4 & $(0.9)$ & $0.6(0.3)$ & 16.3 & $(1.0)$ & 3.8 & $(0.5)$ & 10.0 & $(1.1)$ & 2.3 & $(0.6)$ & 16.3 & $(1.0)$ & 3.8 & $(0.5)$ \\
\hline indirect savings & 3.0 & $(0.6)$ & $2.7(1.1)$ & -11.6 & $(-0.7)$ & -4.2 & $(-0.6)$ & -0.8 & $(-0.1)$ & 1.3 & $(0.3)$ & -11.6 & $(-0.7)$ & -4.2 & $(-0.6)$ \\
\hline combined savings & 16.7 & $(3.3)$ & $8.9(3.8)$ & -7.5 & $(-0.5)$ & -6.3 & $(-0.9)$ & 8.2 & $(0.9)$ & 4.3 & $(1.0)$ & -7.5 & $(-0.5)$ & -6.3 & $(-0.9)$ \\
\hline \multicolumn{16}{|l|}{ Office } \\
\hline Base energy expenditure & 929 & & 475 & 1422 & & 681 & & 929 & & 475 & & 1422 & & 681 & \\
\hline \multicolumn{16}{|l|}{ Savings } \\
\hline reflective roof savings & 29.5 & $(3.2)$ & $10.3(2.2)$ & 22.9 & $(1.6)$ & 5.1 & $(0.7)$ & 29.5 & $(3.2)$ & 10.3 & $(2.2)$ & 22.9 & $(1.6)$ & 5.1 & $(0.7)$ \\
\hline shade tree savings & 48.5 & $(5.2)$ & $17.5(3.7)$ & 40.8 & $(2.9)$ & 10.9 & $(1.6)$ & 48.5 & $(5.2)$ & 17.5 & $(3.7)$ & 40.8 & (2.9) & 10.9 & $(1.6)$ \\
\hline wind shield savings & 0.8 & $(0.1)$ & $3.1(0.6)$ & 7.4 & $(0.5)$ & 8.1 & $(1.2)$ & 0.8 & $(0.1)$ & 3.1 & $(0.6)$ & 7.4 & $(0.5)$ & 8.1 & $(1.2)$ \\
\hline indirect savings & 20.9 & $(2.3)$ & $11.2(2.4)$ & 13.5 & $(0.9)$ & 5.4 & $(0.8)$ & 20.9 & $(2.3)$ & 11.2 & $(2.4)$ & 13.5 & $(0.9)$ & 5.4 & $(0.8)$ \\
\hline combined savings & 99.6 & $(10.7)$ & $42.1(8.8)$ & 84.6 & $(5.9)$ & 29.4 & $(4.3)$ & 99.6 & $(10.7)$ & 42.1 & $(8.8)$ & 84.6 & $(5.9)$ & 29.4 & $(4.3)$ \\
\hline \multicolumn{16}{|l|}{ Retail Store } \\
\hline Base energy expenditure & 802 & & 338 & 1070 & & 415 & & 802 & & 338 & & 1070 & & 415 & \\
\hline \multicolumn{16}{|l|}{ Savings } \\
\hline reflective roof savings & 40.7 & $(5.1)$ & $13.0(3.9)$ & 36.0 & $(3.4)$ & 8.6 & $(2.1)$ & 40.7 & $(5.1)$ & 13.0 & $(3.9)$ & 36.0 & $(3.4)$ & 8.6 & $(2.1)$ \\
\hline shade tree savings & 35.6 & $(4.4)$ & $13.2(3.9)$ & 35.5 & $(3.3)$ & 12.3 & $(3.0)$ & 35.6 & $(4.4)$ & 13.2 & $(3.9)$ & 35.5 & (3.3) & 12.3 & $(3.0)$ \\
\hline wind shield savings & 2.1 & $(0.3)$ & $3.3(1.0)$ & 11.6 & $(1.1)$ & 9.4 & $(2.3)$ & 2.1 & $(0.3)$ & 3.3 & $(1.0)$ & 11.6 & $(1.1)$ & 9.4 & (2.3) \\
\hline indirect savings & 19.8 & $(2.5)$ & $9.3 \quad(2.8)$ & 15.1 & $(1.4)$ & 6.9 & $(1.7)$ & 19.8 & $(2.5)$ & 9.3 & $(2.8)$ & 15.1 & (1.4) & 6.9 & (1.7) \\
\hline combined savings & 98.9 & $(12.3)$ & $39.4(11.7)$ & 98.2 & $(9.2)$ & 37.1 & $(8.9)$ & 98.9 & $(12.3)$ & 39.4 & (11.7) & 98.2 & $(9.2)$ & 37.1 & $(8.9)$ \\
\hline
\end{tabular}


Table 6. Estimates of cooling and heating annual energy savings and avoided peak power from Heat Island Reduction strategies for residential and commercial buildings in The Greater Toronto Area. Direct savings are from the use of solar-reflective roofs, strategic placement of deciduous shade trees and windshielding vegetation. Indirect savings include the effect of reduced ambient air temperature from a modified urban fabric.

\begin{tabular}{|c|c|c|c|c|c|c|c|c|}
\hline \multirow{3}{*}{$\begin{array}{c}\text { building type } \\
\& \\
\text { mitigation strategy } \\
\end{array}$} & \multicolumn{4}{|c|}{ gas heat } & \multirow{2}{*}{\multicolumn{2}{|c|}{$\begin{array}{c}\text { electric heat } \\
\text { electricity [GWh] }\end{array}$}} & \multirow{2}{*}{\multicolumn{2}{|c|}{$\begin{array}{l}\text { gas \& electric hea } \\
\text { peak power [MW] }\end{array}$}} \\
\hline & \multicolumn{2}{|c|}{ electricity [GWh] } & \multicolumn{2}{|c|}{ gas $[\mathrm{PJ}]$} & & & & \\
\hline & Pre-1980 & $1980+$ & Pre-1980 & $1980+$ & Pre-1980 & $1980+$ & Pre-1980 & $1980+$ \\
\hline \multicolumn{9}{|l|}{$\begin{array}{l}\text { Residence: Single-Familv } \\
\end{array}$} \\
\hline Energy use \& demand & 207 & 49 & 14.8 & 3.8 & 467 & 16 & 615 & 137 \\
\hline \multicolumn{9}{|l|}{ Savings } \\
\hline reflective roof savings & 18.4 & 4.1 & -0.19 & -0.04 & -2.0 & 0.0 & 27 & 6 \\
\hline shade tree savings & 26.2 & 5.8 & -0.20 & -0.06 & -0.7 & 0.0 & 74 & 14 \\
\hline wind shield savings & -6.3 & -2.0 & 0.51 & 0.09 & 12.0 & 0.2 & 0 & -1 \\
\hline indirect savings & 17.3 & 4.0 & -0.17 & -0.04 & -3.2 & -0.1 & 29 & 7 \\
\hline \multirow{2}{*}{\multicolumn{9}{|c|}{ Apartment }} \\
\hline & & & & & & & & \\
\hline Energy use \& demand & 8 & 1 & 0.4 & 0.0 & 17 & 16 & 22 & 5 \\
\hline \multicolumn{9}{|l|}{ Savings } \\
\hline reflective roof savings & 0.7 & 0.0 & -0.01 & 0.00 & -0.1 & -0.1 & 1 & 0 \\
\hline shade tree savings & 0.8 & 0.1 & -0.01 & 0.00 & 0.0 & 0.0 & 2 & 1 \\
\hline wind shield savings & -0.1 & 0.0 & 0.01 & 0.00 & 0.2 & 0.1 & 0 & 0 \\
\hline indirect savings & 0.5 & 0.0 & 0.00 & 0.00 & -0.1 & -0.1 & 1 & 0 \\
\hline combined savings & 2.0 & 0.2 & -0.01 & 0.00 & -0.1 & -0.1 & 5 & 1 \\
\hline \multicolumn{9}{|l|}{ Residence: Row-House } \\
\hline Energy use \& demand & 70 & 6 & 3.9 & 0.3 & 86 & 94 & 179 & 38 \\
\hline \multicolumn{9}{|l|}{ Savings } \\
\hline reflective roof savings & 6.2 & 0.5 & -0.06 & 0.00 & -0.5 & -0.7 & 9 & 2 \\
\hline shade tree savings & 7.0 & 0.7 & -0.05 & 0.00 & -0.2 & -0.1 & 17 & 4 \\
\hline wind shield savings & -1.0 & -0.1 & 0.06 & 0.00 & 0.9 & 0.5 & -1 & 0 \\
\hline indirect savings & 4.5 & 0.5 & -0.04 & 0.00 & -0.6 & -0.6 & 11 & 2 \\
\hline \multirow{2}{*}{\multicolumn{9}{|c|}{ Office }} \\
\hline & & & & & & & & \\
\hline Energy use \& demand & 88 & 29 & 0.7 & 0.2 & 0 & 0 & 86 & 31 \\
\hline \multicolumn{9}{|l|}{ Savings } \\
\hline reflective roof savings & 4.7 & 1.2 & -0.01 & 0.00 & 0.0 & 0.0 & 3 & 1 \\
\hline shade tree savings & 7.7 & 1.9 & -0.01 & -0.01 & 0.0 & 0.0 & 5 & 2 \\
\hline wind shield savings & -0.4 & 0.0 & 0.01 & 0.00 & 0.0 & 0.0 & 0 & 0 \\
\hline indirect savings & 3.3 & 1.2 & 0.00 & 0.00 & 0.0 & 0.0 & 5 & 2 \\
\hline combined savings & 15.2 & 4.3 & -0.01 & -0.01 & 0.0 & 0.0 & 14 & 4 \\
\hline \multicolumn{9}{|l|}{ Retail Store } \\
\hline Energy use \& demand & 223 & 19 & 0.9 & 0.1 & 0 & 0 & 146 & 15 \\
\hline \multicolumn{9}{|l|}{$\begin{array}{l}\text { Savings } \\
\text { Sallu }\end{array}$} \\
\hline reflective roof savings & 15.5 & 1.1 & -0.02 & 0.00 & 0.0 & 0.0 & 8 & 1 \\
\hline shade tree savings & 13.1 & 1.0 & -0.01 & 0.00 & 0.0 & 0.0 & 6 & 1 \\
\hline wind shield savings & -1.2 & -0.1 & 0.03 & 0.00 & 0.0 & 0.0 & 1 & 0 \\
\hline indirect savings & 7.7 & 0.7 & -0.01 & 0.00 & 0.0 & 0.0 & 7 & 1 \\
\hline combined savings & 35.0 & 2.7 & 0.00 & 0.00 & 0.0 & 0.0 & 21 & 2 \\
\hline \multicolumn{9}{|l|}{ Total } \\
\hline Energy use \& demand & 596 & 103 & 20.7 & 4.4 & 570 & 125 & 1048 & 226 \\
\hline \multicolumn{9}{|l|}{ Savings } \\
\hline reflective roof savings & 45.5 & 6.9 & -0.27 & -0.05 & -2.6 & -0.8 & 48.4 & 10.0 \\
\hline shade tree savings & 54.7 & 9.5 & -0.27 & -0.07 & -0.9 & -0.2 & 103.8 & 21.8 \\
\hline wind shield savings & -9.1 & -2.2 & 0.61 & 0.11 & 13.0 & 0.8 & -0.3 & -1.4 \\
\hline indirect savings & 33.3 & 6.5 & -0.22 & -0.05 & -3.9 & -0.8 & 53.5 & 11.5 \\
\hline combined savings & 124.4 & 20.7 & -0.16 & -0.07 & 5.6 & -0.9 & 205 & 42 \\
\hline
\end{tabular}


Table 7. The Greater Toronto Area estimates of cooling and heating annual base energy expenditures and savings $[\mathrm{M} \$]$ from Heat Island Reduction strategies for residential and commercial buildings. Direct savings are from the use of solar-reflective roofs, strategic placement of deciduous shade trees and windshielding vegetation. Indirect savings include the effect of reduced ambient air temperature from a modified urban fabric.

\begin{tabular}{|c|c|c|c|c|c|c|c|c|c|c|}
\hline \multirow{2}{*}{$\begin{array}{c}\text { building type } \\
\& \text { \& } \\
\text { mitigation strategy } \\
\end{array}$} & \multicolumn{5}{|c|}{ Residential gas price of $\$ 5.54 / \mathrm{GJ}$} & \multicolumn{5}{|c|}{ Residential gas price of $\$ 10.84 / \mathbf{G J}$} \\
\hline & \multirow{2}{*}{\multicolumn{4}{|c|}{$\begin{array}{l}\text { Annual energy and savings [M\$] } \\
\text { gas heat } \begin{array}{c}\text { electric heat } \\
\text { Pre-19801980+Pre-1980 } 1980+\end{array} \\
\end{array}$}} & $\begin{array}{l}\text { Total } \\
\text { [M\$] }\end{array}$ & $\begin{array}{r}\text { Annua } \\
\text { gas } \\
\text { Pre-198 }\end{array}$ & $\begin{array}{l}\text { energy } \\
\text { eat } \\
1980+\end{array}$ & $\begin{array}{c}\text { and savin } \\
\text { electric } \\
\text { Pre-1980 }\end{array}$ & $\begin{array}{l}\text { Igs [M\$] } \\
\text { c heat } \\
1980+\end{array}$ & $\begin{array}{l}\text { Total } \\
\text { [M\$] }\end{array}$ \\
\hline \multicolumn{7}{|c|}{ Residence: Single-Family } & & & & \\
\hline Base energy expenditure & 99 & 25 & 39 & 1 & 165 & 176 & 46 & 39 & 1 & 262 \\
\hline $\begin{array}{l}\text { Savings } \\
\text { reflective roof savings } \\
\text { shade tree savings } \\
\text { wind shield savings } \\
\text { indirect savings } \\
\text { combined savings } \\
\text { Apartment }\end{array}$ & $\begin{array}{l}0.5 \\
1.1 \\
2.3 \\
0.5 \\
4.4\end{array}$ & $\begin{array}{l}0.1 \\
0.2 \\
0.3 \\
0.1 \\
0.7\end{array}$ & $\begin{array}{c}-0.2 \\
-0.1 \\
1.0 \\
-0.3 \\
0.5\end{array}$ & $\begin{array}{l}0.0 \\
0.0 \\
0.0 \\
0.0 \\
0.0\end{array}$ & $\begin{array}{l}0.5 \\
1.2 \\
3.6 \\
0.4 \\
5.6\end{array}$ & $\begin{array}{c}-0.5 \\
0.1 \\
4.9 \\
-0.3 \\
4.2\end{array}$ & $\begin{array}{c}-0.1 \\
-0.2 \\
0.8 \\
-0.1 \\
0.5\end{array}$ & $\begin{array}{c}-0.2 \\
-0.1 \\
1.0 \\
-0.3 \\
0.5\end{array}$ & $\begin{array}{l}0.0 \\
0.0 \\
0.0 \\
0.0 \\
0.0\end{array}$ & $\begin{array}{c}-0.7 \\
-0.2 \\
6.8 \\
-0.7 \\
5.1\end{array}$ \\
\hline Base energy expenditure & 3 & 0 & 1 & 1 & 6 & 6 & 0 & 1 & 1 & 9 \\
\hline $\begin{array}{l}\text { Savings } \\
\text { reflective roof savings } \\
\text { shade tree savings } \\
\text { wind shield savings } \\
\text { indirect savings } \\
\text { combined savings }\end{array}$ & $\begin{array}{l}0.0 \\
0.0 \\
0.0 \\
0.0 \\
0.1\end{array}$ & $\begin{array}{l}0.0 \\
0.0 \\
0.0 \\
0.0 \\
0.0\end{array}$ & $\begin{array}{l}0.0 \\
0.0 \\
0.0 \\
0.0 \\
0.0\end{array}$ & $\begin{array}{l}0.0 \\
0.0 \\
0.0 \\
0.0 \\
0.0\end{array}$ & $\begin{array}{l}0.0 \\
0.0 \\
0.1 \\
0.0 \\
0.1\end{array}$ & $\begin{array}{l}0.0 \\
0.0 \\
0.1 \\
0.0 \\
0.1\end{array}$ & $\begin{array}{l}0.0 \\
0.0 \\
0.0 \\
0.0 \\
0.0\end{array}$ & $\begin{array}{l}0.0 \\
0.0 \\
0.0 \\
0.0 \\
0.0\end{array}$ & $\begin{array}{l}0.0 \\
0.0 \\
0.0 \\
0.0 \\
0.0\end{array}$ & $\begin{array}{l}0.0 \\
0.0 \\
0.1 \\
0.0 \\
0.0\end{array}$ \\
\hline \multicolumn{11}{|l|}{ Residence: Row-House } \\
\hline Base energy expenditure & 27 & 2 & 7 & 8 & 45 & 48 & 4 & 7 & 8 & 66 \\
\hline $\begin{array}{l}\text { Savings } \\
\text { reflective roof savings } \\
\text { shade tree savings } \\
\text { wind shield savings } \\
\text { indirect savings } \\
\text { combined savings }\end{array}$ & $\begin{array}{l}0.2 \\
0.3 \\
0.2 \\
0.2 \\
0.9\end{array}$ & $\begin{array}{l}0.0 \\
0.0 \\
0.0 \\
0.0 \\
0.1\end{array}$ & $\begin{array}{c}0.0 \\
0.0 \\
0.1 \\
-0.1 \\
0.0\end{array}$ & $\begin{array}{c}-0.1 \\
0.0 \\
0.0 \\
0.0 \\
-0.1\end{array}$ & $\begin{array}{l}0.1 \\
0.3 \\
0.4 \\
0.1 \\
0.9\end{array}$ & $\begin{array}{c}-0.1 \\
0.1 \\
0.5 \\
0.0 \\
0.4\end{array}$ & $\begin{array}{l}0.0 \\
0.0 \\
0.0 \\
0.0 \\
0.0\end{array}$ & $\begin{array}{c}0.0 \\
0.0 \\
0.1 \\
-0.1 \\
0.0\end{array}$ & $\begin{array}{c}-0.1 \\
0.0 \\
0.0 \\
0.0 \\
-0.1\end{array}$ & $\begin{array}{c}-0.2 \\
0.1 \\
0.7 \\
-0.1 \\
0.4\end{array}$ \\
\hline \multicolumn{11}{|l|}{ Office } \\
\hline Base energy expenditure & 11 & 4 & 0 & 0 & 15 & 11 & 4 & 0 & 0 & 15 \\
\hline Base energy expenditure & 24 & 2 & 0 & 0 & 26 & 24 & 2 & 0 & 0 & 26 \\
\hline $\begin{array}{l}\text { Savings } \\
\text { reflective roof savings } \\
\text { shade tree savings } \\
\text { wind shield savings } \\
\text { indirect savings } \\
\text { combined savings }\end{array}$ & $\begin{array}{l}1.2 \\
1.1 \\
0.1 \\
0.6 \\
2.9\end{array}$ & $\begin{array}{l}0.1 \\
0.1 \\
0.0 \\
0.1 \\
0.2\end{array}$ & $\begin{array}{l}0.0 \\
0.0 \\
0.0 \\
0.0 \\
0.0\end{array}$ & $\begin{array}{l}0.0 \\
0.0 \\
0.0 \\
0.0 \\
0.0\end{array}$ & $\begin{array}{l}1.3 \\
1.1 \\
0.1 \\
0.6 \\
3.1\end{array}$ & $\begin{array}{l}1.2 \\
1.1 \\
0.1 \\
0.6 \\
2.9\end{array}$ & $\begin{array}{l}0.1 \\
0.1 \\
0.0 \\
0.1 \\
0.2\end{array}$ & $\begin{array}{l}0.0 \\
0.0 \\
0.0 \\
0.0 \\
0.0\end{array}$ & $\begin{array}{l}0.0 \\
0.0 \\
0.0 \\
0.0 \\
0.0\end{array}$ & $\begin{array}{l}1.3 \\
1.1 \\
0.1 \\
0.6 \\
3.1\end{array}$ \\
\hline \multicolumn{11}{|l|}{ Total } \\
\hline Base energy expenditure & 164 & 33 & 48 & 10 & 256 & 273 & 57 & 48 & 10 & 388 \\
\hline $\begin{array}{l}\text { Savings } \\
\text { reflective roof savings } \\
\text { shade tree savings } \\
\text { wind shield savings } \\
\text { indirect savings } \\
\text { combined savings }\end{array}$ & $\begin{array}{l}2.3 \\
3.1 \\
2.6 \\
1.6 \\
9.6 \\
\end{array}$ & $\begin{array}{l}0.3 \\
0.4 \\
0.4 \\
0.3 \\
1.3\end{array}$ & $\begin{array}{c}-0.2 \\
-0.1 \\
1.1 \\
-0.3 \\
0.5\end{array}$ & $\begin{array}{c}-0.1 \\
0.0 \\
0.1 \\
-0.1 \\
-0.1\end{array}$ & $\begin{array}{c}2.3 \\
3.4 \\
4.2 \\
1.4 \\
11.3\end{array}$ & $\begin{array}{l}0.8 \\
1.7 \\
5.8 \\
0.4 \\
8.7 \\
\end{array}$ & $\begin{array}{l}0.0 \\
0.0 \\
0.9 \\
0.0 \\
1.0\end{array}$ & $\begin{array}{c}-0.2 \\
-0.1 \\
1.1 \\
-0.3 \\
0.5 \\
\end{array}$ & $\begin{array}{c}-0.1 \\
0.0 \\
0.1 \\
-0.1 \\
-0.1 \\
\end{array}$ & $\begin{array}{c}0.5 \\
1.6 \\
7.9 \\
0.0 \\
10.1\end{array}$ \\
\hline
\end{tabular}


